Esta sección contiene los artículos originales de las Revistas de Pediatría de las Sociedades de Pediatría del Cono Sur seleccionados en el XV encuentro de Editores, Asunción, Paraguay 2010, para ser publicados por los países integrantes durante el año 2011.

\title{
Hipernatremia neonatal: factores de riesgo
}

\author{
ADRIANA ASTURIZAGA MALLEA ${ }^{1}$, AC. EDUARDO MAZZI GONZALES DE PRADA²
}

1. Médico Pediatra. Ex residente de Pediatría- Hospital del Niño Luis Ovidio Aliaga Uría. La Paz.

2. Pediatra- Perinatólogo. Hospital del Niño Luis Ovidio Aliaga Uría. La Paz. Profesor Emérito de Pediatría. Facultad de Medicina. U.M.S.A.

\begin{abstract}
\section{Hypernatremia in newborn. Risk factors}

Introduction: Neonatal hypernatremic dehydration is a very common problem and now frequently described in the literature. Objectives: To establish risk factors associated with hypernatremic dehydration. Design: Retrospective, descriptive and analytical case control study. Place: Neonatal ward of the Hospital del Niño "Ovidio Aliaga Uría”. La Paz. Bolivia. Methods: 64 newborns admitted with dehydration. Case control study, from February 2008 to January 2009. We defined cases to neonates with hypernatremic dehydration and controls, neonates with hyponatremic or isonatremic dehydration. The variable of the study were: maternal age, age of the neonate, percentage of weight loss and mother- son days in the hospital, information to mother before discharge, socio economic status, serum sodium and bilirubin levels, and cranial ultrasound study. Results: Of 70 neonates, six were excluded because they were immediately transferred to intensive care, of the 64 patients, 31 had hypernatremic dehydration and 33 isonatremic or hyponatremic dehydration. The most important risk factors for hypernatremic dehydration were: more than $10 \%$ weight loss, no maternal information about the correct breast feeding technique, early discharge and the association with jaundice. The loss of $10 \%$ or more of the newborn weight increases 47 more times the risk of developing hypernatremic dehydration. Conclusions: Hypernatremic dehydration is common in neonates with more tan $10 \%$ weight loss, usually secondary to breast feeding difficulties, poor mother information about the correct breast feeding technique, early discharge and lack of follow up. We need to improve and correct these problems.
\end{abstract}

(Key words: Hypernatremia, dehydration, neonates).

Rev Soc Bol Ped 2009; 48 (3): 153-8

\section{RESUMEN}

Introducción: La deshidratación hipernatrémica neonatal es un problema frecuente de observar y que se la describe con mayor frecuencia. Objetivos: Determinar los factores de riesgo relacionados con la hipernatremia neonatal. Diseño: Estudio es retrospectivo, prolectivo, descriptivo, analítico y de caso control. Lugar: Unidad de Neonatología del Hospital del Niño “Ovidio Aliaga Uría” de la ciudad de La Paz, Bolivia Material y Métodos: Estudio de caso-control que se llevo a cabo desde febrero del 2008 a enero del 2009. Se definió 
como casos los neonatos que ingresaron con deshidratación hipernatrémica y controles a los con deshidratación hiponatrémica o isonatrémica. Variables estudiadas: edad materna, edad del recién nacido, porcentaje de pérdida de peso, días de internación como binomio madre-hijo, información materna en el momento del alta, nivel de sodio sérico, nivel de bilirrubinas séricas y ecografía transfontanelar. Resultados: De 70 neonatos, fueron excluidos seis, porque inmediatamente a su ingreso fueron trasladados a Cuidado Intensivo, quedando 64 pacientes de los cuales 31 neonatos presentaban deshidratación hipernatrémica y 33 neonatos deshidratación isonatrémica o hiponatrémica. De las variables estudiadas, la pérdida de peso mayor al 10\%, la deficiente información alimentaria, el alta precoz y la asociación con ictericia neonatal, son los factores de riesgo más importantes para desarrolla hipernatremia neonatal. Conclusiones: La deshidratación hipernatrémica es frecuente de observar en los neonatos con una pérdida de peso mayor al 10\%, secundaria a una deshidratación por inadecuada lactancia materna y escasa información a la madre sobre la correcta alimentación de su bebe, estancia hospitalaria abreviada y falta de seguimiento apropiado.

(Palabras clave: Hipernatremia, deshidratación, neonatos).

Rev Soc Bol Ped 2009; 48 (3): 153-8

ESTE TRABAJO LO PUEDE ENCONTRAR EN EXTENSO EN WWW.SciELO.ORG 